\title{
Waste-to-Energy: An Opportunity to Increase Renewable Energy Share and Reduce Ecological Footprint in Small Island Developing States (SIDS)
}

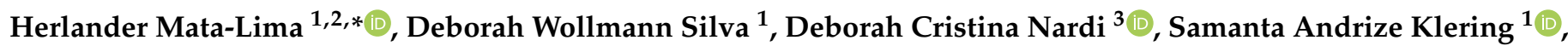 \\ Thays Car Feliciano de Oliveira ${ }^{1}$ and Fernando Morgado-Dias ${ }^{4, *}$ (i) \\ 1 ILATIT-Instituto Latino Americano de Tecnologia, Infraestrutura e Território, \\ Universidade Federal da Integração Latino-Americana, Paraná 85866-000, PR, Brazil; \\ dw.silva.2019@aluno.unila.edu.br (D.W.S.); samaandri@hotmail.com (S.A.K.); \\ thayscarf@gmail.com (T.C.F.d.O.) \\ 2 IST-Energy Initiative, Instituto Superior Técnico, Universidade de Lisboa, 1049-001 Lisboa, Portugal \\ 3 Department of Building, Civil \& Environmental Engineering, Concordia University, \\ Montréal, QC H3A 2T5, Canada; deborahnardii@gmail.com \\ 4 ITI/Larsys/ARDITI-Interactive Technology Institute and Universidade da Madeira, \\ 9000-081 Funchal, Portugal \\ * Correspondence: hmatalima@ist.utl.pt (H.M.-L.); morgado@uma.pt (F.M.-D.)
}

check for updates

Citation: Mata-Lima, H.; Silva, D.W.; Nardi, D.C.; Klering, S.A.; de Oliveira, T.C.F.; Morgado-Dias, F. Waste-toEnergy: An Opportunity to Increase Renewable Energy Share and Reduce Ecological Footprint in Small Island Developing States (SIDS). Energies 2021, 14, 7586. https://doi.org/ $10.3390 /$ en14227586

Academic Editor: Ulugbek Azimov

Received: 6 October 2021

Accepted: 2 November 2021

Published: 12 November 2021

Publisher's Note: MDPI stays neutral with regard to jurisdictional claims in published maps and institutional affiliations.

Copyright: (c) 2021 by the authors. Licensee MDPI, Basel, Switzerland. This article is an open access article distributed under the terms and conditions of the Creative Commons Attribution (CC BY) license (https:// creativecommons.org/licenses/by/ $4.0 /)$.

\begin{abstract}
Small Island Developing States (SIDSs) are faced with challenges such as reducing the share of fossil energy and waste landfilling. This work summarizes the main aspects of 53 SIDSs that constrain economic development, energy sources, and waste management strategies. An integrative bibliographical review is conducted to synthesize the state-of-the-art of waste-to-energy (WtE) strategies and compare the technologies in light of their suitability to SIDS. The findings show that considering the large amount of waste produced annually, WtE technologies are of the utmost importance to reduce ecological footprints (EFs) and greenhouse gas (GHG) emissions, and to increase the share of renewable energy with the installation of incineration plants with energy recovery to replace fossil fuel power plants. Although WtE is recommended for all SIDSs, the Atlantic, Indian Ocean, Mediterranean, and South China Sea (AIMS) countries exhibit higher population density (1509 inhab $/ \mathrm{km}^{2}$ ) and a high share of fossil fuel in their electricity mix, so that there is greater urgency to replace landfilling practices with $\mathrm{WtE}$. The estimation of potential power generation capacity (MWh) from annual municipal solid waste (MSW) in each SIDS as well as the reduced land area required demonstrate the feasibility of $\mathrm{WtE}$ technologies. Only $3 \%$ of the landfill area is necessary for buildings and landscaping associated with a WtE plant able to treat 1 million tons of MSW, considering a 30 year lifespan. Furthermore, incineration with energy recovery benefits from high penetration worldwide and affordable cost among thermochemical processes.
\end{abstract}

Keywords: waste-to-energy; incineration; renewable energy; environmental impacts; sustainability; Small Island Developing State

\section{Background and Introduction}

\subsection{General Aspects of Waste, Energy, and Sustainability}

Primary energy consumption and demophoric growth (population + industrial growth with massive urbanization) are among major contributors to greenhouse gas (GHG) emissions [1] and deterioration of ecosystem services [2]. According to the International Energy Agency (IEA), the urban area is responsible for two thirds of primary energy consumption, which represents $71 \%$ of direct energy-related GHGs [3]. On the other hand, the economy nowadays-commonly named the carbon economy due to over dependence on non-renewable energy sources [4] - has been running with more than $56 \%$ of world population concentrated in urban area as a consequence of demophoric growth (with a 
remarkable high rate of urbanization and industrialization) $[5,6]$; this share has an average of $58.4 \%$ in Small Island Development States (SIDSs [7]) and can reach $100 \%$ in some of them (e.g., Anguilla, Cayman Islands, Nauru, Guadeloupe, and Singapore) [8]. The current pattern of development exerts negative impacts on the rate of energy consumption (causing depletion of the ozone layer because of the excessive use of fossil fuel); waste production (e.g., increase in MSW is related to higher standards of living, and rise in population); and subsequent air, soil, and water pollution [2,9].

On the other hand, the carrying capacity of the planet cannot afford the current rate of demophoric growth and the resulting waste and pollution [10-12], with the ecosystem services and ecological footprint (EF) being more negatively affected in SIDS. Hence, sustainable development principles are receiving special attention in the international agenda, and recently, following the Millennium Development Goals (MDG) [13], the United Nations (UN) defined seventeen Sustainable Development Goals (SDG) to be achieved by $2030[14,15]$. Energy efficiency, resource depletion, and pollution control concerns are amongst the 17 SDGs, namely through goals no. 7 (Ensure access to affordable, reliable, sustainable, and modern energy for all), no. 12 (Ensure sustainable consumption and production patterns), and no. 13 (Take urgent action to combat climate change and its impacts).

Traditionally, the Small Island Developing States (SIDSs) use conventional thermoelectric power plants (based on imported fossil fuel) to produce energy with high financial and environmental costs [16], since they do not have enough natural capital (e.g., hydrographical conditions to develop hydropower). SIDS stands for a group of small developing economies that share certain similarities in terms of their remote location and isolation from developed economies, population density, land scarcity, and challenges in several sectors of climate change, environment, energy, and economy, as well as a strong dependence on the international market [17].

SIDSs analyzed hereby comprise the following three main geographic regions: Caribbean SIDSs (24); Pacific SIDSs (20); and Atlantic, Indian Ocean, Mediterranean, and South China (AIMS) (9) SIDSs [18]. These countries have many socio-economic and environmental constraints and high dependence on developed economies, as highlighted in Section 3.

Mitigation of energy cost and environmental impacts in SIDSs has been very challenging due to resource (energy sources and land) scarcity $[2,16]$. Therefore, waste-to-energy (WtE) can be an alternative to (1) increase the penetration of renewable energy, (2) reduce energy cost and increase reliability, (3) reduce the amount of waste disposal and so increase the lifetime of landfills, and (4) reduce the carbon and ecological footprints of demophoric growth. Furthermore, there are several reasons to believe that $\mathrm{WtE}$ is likely to be cost-effective in SIDSs because they have an average waste production per capita ( 1.29 kg/capita/day) similar to the countries of the Organization for Economic Co-Operation and Development (OECD, 1.35 kg/capita/day) [17], and affordable cost of waste collection and transportation to power plants owing to the high density of urban settlement, and thus small travel distances to power plants and landfills. As the amount of MSW subjected to landfilling in some European countries (Germany, the Netherlands, Austria, Belgium, Sweden, and Denmark) is already less than 5\% [19], the employed technology must be used to reduce energy cost and mitigate environmental issues in SIDSs (e.g., the landfill area cannot be reused for another purpose and a new greenfield must be converted to landfill, which increases the EF). It is worth mentioning that the European Union emphasized, with the directive on energy efficiency [20], the necessity to valorize electricity production from waste incineration industries at the regional scale and indicates (see [21]) that from 2035 only $10 \%$ of waste can be disposed of in landfills. SIDSs should strive to reach this target due to their peculiarities (e.g., low land availability, high urban density, and dependence on fossil energy) that foster the relevance of the WtE strategy. As a useful indicator, it is important to stress that, in the United States, $123 \mathrm{~L}$ of gasoline, $57 \mathrm{~L}$ of diesel, $79 \mathrm{~kg}$ of other Fischer-Tropsch (FT) products (e.g., diesel, gasoline, liquefied 
petroleum gas), and $193 \mathrm{kWh}$ of electricity are produced from the conversion of one ton of MSW via gasification and FT methods [22].

\subsection{Research Rationale, Objective, Scope, and Key Contributions}

The cost of energy in SIDSs is among the highest in the world owing to high fuel transportation costs, which contribute to a higher price per unit of electricity compared to non-island countries [16]. Despite the increasing waste production due to demophoric growth, most SIDSs do not have appropriate infrastructure for waste collection and treatment, nor appropriate landfill for waste disposal with biogas recovery. Wastes are still dumped into uncontrolled landfills [17], which means that leachate is released to soil and water and that biogas is not collected to produce energy.

In this research, objectives have been made to investigate the main aspects of different WtE technologies as well their relevance for SIDS, the associated environmental aspects and impacts, and indicators (e.g., demographic, physiographic, and economic) that make $\mathrm{WtE}$ technologies an asset for SIDSs as way to mitigate the carbon footprint and global ecological footprint by reducing waste landfilling and eliminating illegal dumping and backyard burning. Bearing in mind the aforementioned objectives, and the peculiarities of SIDSs, the following research question was set: Considering the physiographic and socio-economic factors of SIDSs, what sort of waste management technologies are most recommended to reduce ecological footprint and GHG emissions?

The scope of this work is limited to SIDSs-according to their geographical, economic, and sociodemographic conditions-but is also applicable to microregions (small municipalities far from metropolitan areas) of large countries.

As a key contribution, it is important to highlight that the characterization of the state-of-the-art on $\mathrm{WtE}$, the environmental aspects and impacts of waste management technologies, the synthesis of relevant indicators across SIDSs, and the economic and environmental potentials of MSW are expected to provide local (SIDS) practitioners (including researchers) and decision makers with options for sounder waste management considering the waste-energy nexus and Sustainable Development Goals 7 (SDG 7: Ensure access to affordable, reliable, sustainable, and modern energy for all) and 11 (SDG 11: Make cities inclusive, safe, resilient, and sustainable).

\section{Research Approach}

The methodology adopted in this article can be divided into three steps as follows: First, we performed an integrative literature review to characterize (1) socio-economic profile of SIDSs in terms of population density, urban population, and gross domestic product (GDP) per capita, as well as (2) waste production; and to (3) verify the penetration of $\mathrm{WtE}$ technologies in these countries. The integrative literature review is suitable when the subjects of interest are spread out, and it entails a research procedure that reviews, critiques, and synthesizes relevant literature in an integrated way to draw new frameworks and perspectives on a specific subject (see Torraco [23]). It should begin with a clear statement of purpose [24], as stated in the above sentence, and an appropriate search process to conduct studies that demand extensive scientific analysis of the previous contributions to the research subject, ensuring that the databases searched provide a good coverage of the topic. The adequacy of such reviews relies on the fact that they encompass articles that utilize a broad range of methodologies and present the steps outlining how the papers were selected for inclusion in the review to synthesize the literature on a research topic to, for instance, enable perspectives to emerge (see Snyder [25]). Secondly, efforts were made to establish a set of relevant factors-waste amount and composition (\% organic matter), effectiveness of recycling (relies on stakeholder awareness and engagement), and moisture content of the refuse- that contribute to the feasibility of WtE technologies, as well their electrical efficiency. Third, a WtE management strategy was described to highlight corresponding advantages and disadvantages concerning technical, environmental, and 
socioeconomic aspects related to each technology, and how they constrain each other. This step also included a synthesis of environmental aspects and impacts of WtE technologies.

For the literature review strategy, the first step was to search for literature containing relevant data/information on WtE management. The search was disaggregated into three regions: (1) studies about socio-economic profile of SIDSs, (2) studies concerning waste and the WtE arena in SIDSs, and (3) studies about WtE and environmental impacts in the international arena. Nevertheless, articles that discuss the use of WtE technologies in environmental and socioeconomic perspective were included as well.

The search was firstly conducted using the search string "waste-to-energy AND SIDS" in major relevant bibliographic databases such as SCOPUS, ScienceDirect, and PubMed, for the years 1977 to 2021. After that, a search using "waste-to-energy AND OCED OR sustainability OR environment" was also performed, for the same period, to obtain additional information regarding WtE application in other regions as well the environmental context. The abstracts of potentially relevant articles were examined to determine if they included useful information, and then full texts of selected articles were downloaded. In addition, reference lists of downloaded articles were examined for any complementary studies, such as those using different terminology. These procedures yielded 90 studies that met the criteria for inclusion: reporting data about waste production and management in SIDS, WtE technologies, as well as their socioeconomic and environmental impacts. The review included all studies that met these criteria, not a sample of them.

The next step was to code information from each study into a set of tables, so that overall results could be tabulated and compared.

\section{Main Characteristics of SIDS}

Small Island Developing States (SIDSs) are spatially distributed, as shown in Figure 1. The 53 SIDSs considered hereby exhibit several similarities, such as isolation from developed economies, gross development product (GDP) mainly based in the tourism sector, increasing environmental concerns due to demophoric growth (e.g., waste production, virtual water demand), and other obstacles, as synthesized in Table 1.

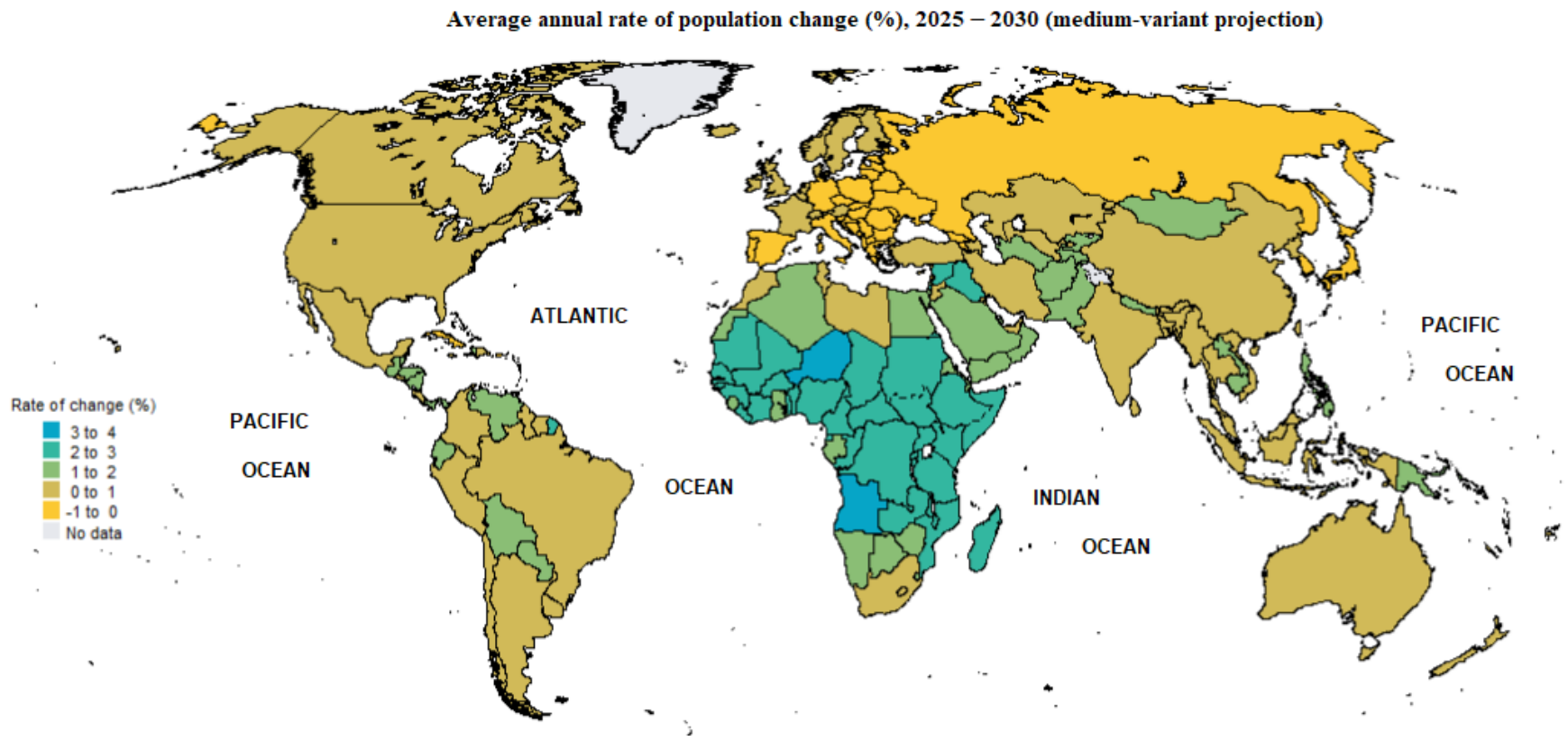

Figure 1. World map with Pacific, Caribbean, and AIMS SIDSs. The group of Small Island Developing States (SIDSs) is composed of countries or territories in the Caribbean (24), Pacific (20), and Atlantic, Indian Ocean, Mediterranean, and South China Sea (AIMS) (9). Source: modified from United Nations, DESA, Population Division, https:// population.un. org/wpp/Maps/, accessed on 20 September 2021. 
Table 1. Obstacles to economic growth and development of SIDS.

\begin{tabular}{|c|c|}
\hline Physical/Environmental Factors & Socio-Economic Factors \\
\hline $\begin{array}{c}\text { Small size (land area) } \\
\text { Insularity (isolation from developed economies and so } \\
\text { high transportation costs) } \\
\text { Environmental vulnerability } \\
\text { Limited resources (e.g., land, water) } \\
\text { Greater effect of climate change } \\
\text { High vulnerability to natural disasters } \\
\text { Sensitive ecosystems } \\
\text { Large output declines after a disaster }\end{array}$ & $\begin{array}{c}\text { Small population } \\
\text { Small economy based essentially in tourism } \\
\text { High share of urban population as well as density } \\
\text { High levels of dependence on international trade due to insularity } \\
\text { Lower literacy rates } \\
\text { Poor governance } \\
\text { Lower per capita income } \\
\text { High dependence on fossil fuel to satisfy energy demand } \\
\text { Fuel imports has a share of } 12 \text { to } 37 \% \text { of total imports } \\
\text { High unemployment } \\
\text { Heavy reliance on foreign aid }\end{array}$ \\
\hline
\end{tabular}

Source: the authors based on Wolf et al. [16], Hampton and Christensen [26], Scheyvens and Momsen [27], Noy [28], and Pratt [29].

The population of SIDSs has been increasing in recent decades, and the total population is now approximately 70.7 million inhabitants, of which 41 million live in urban areas (see Table 2). The high density of populations in urban settlements (Table 2) and tourism growth induce a considerable amount of wastes produced by industries (e.g., hotel, restaurant) and households. However, a number of SIDSs use a small percentage of wastes in energy recovery facilities due to lack of stakeholder (e.g., government authorities, populations) awareness, and because landfilling requires lower investments. The amount of MSW landfilled or disposed of in open dumps in SIDSs is around 70 million tons (Table 2), of which less than $10 \%$ is treated by incineration to produce electricity [30]. Cucchiella et al. [19] stressed that the value of the global waste incineration market has increased from 2008 to 2012 ( $+\$ 1.3$ billion dollars) and will continue to grow ( $+\$ 6.8$ billion dollars from 2012 to 2022).

To overcome the limitation regarding the use of secondary data, the strategy adopted to validate our results was to use only $50 \%$ of MSW to quantify the potential energy that can be produced by WtE technologies in each SIDS. Thus, the results obtained for each SIDS can be fitted by adjusting the MSW production per capita, population, and increasing or decreasing the share of MSW treated in WtE plants (plant efficiency is another variable that can be adjusted).

The situation of SIDSs is complex and demands particular attention in the context of global change, so that in 2012 the General Assembly of the United Nations designated 2014 as the "International Year of Small Island Developing States" to raise awareness on adaptation measures needed for economic, social, and environmental resiliency of SIDS.

Table 2. Description of the main socioeconomic indicators and waste production in SIDS.

\begin{tabular}{|c|c|c|c|c|c|c|c|}
\hline & \multirow{2}{*}{ Country } & \multicolumn{2}{|c|}{ Population (Thousands) ${ }^{a}$} & \multirow{2}{*}{$\underset{\left(\mathrm{km}^{2}\right)}{\text { Land Area }}$} & \multirow{2}{*}{$\begin{array}{c}\text { Urban } \\
\text { Population } \\
\text { (UP) (\%) }(\%)\end{array}$} & \multirow{2}{*}{$\begin{array}{c}\text { GDP Per } \\
\text { Capita (US\$) }\end{array}$} & \multirow{2}{*}{$\begin{array}{c}\text { MSW } \\
\text { Collected } \\
\left(10^{3} \text { tons }\right)\end{array}$} \\
\hline & & 2019 & 2030 & & & & \\
\hline \multirow{7}{*}{$\begin{array}{l}\text { CARIBBEAN } \\
\text { (24): urban } \\
\text { population } \\
\text { (UP) }(59.1 \%)\end{array}$} & Anguilla & 15 & 16 & 91.0 & 100 & 25,529 & $15(2008)$ \\
\hline & $\begin{array}{l}\text { Antigua and } \\
\text { Barbuda }\end{array}$ & 97 & 105 & 440.0 & 75 & 17,113 & $138(2014)$ \\
\hline & Aruba & 106 & 110 & 180.0 & 44 & 29,008 & nd \\
\hline & Bahamas & 389 & 427 & $13,880.0$ & 83 & 28,608 & $240(2005)$ \\
\hline & Barbados & 287 & 289 & 431.0 & 32 & 18,148 & nd \\
\hline & Belize & 390 & 468 & $22,966.0$ & 47 & 4815 & $69(2000)$ \\
\hline & $\begin{array}{l}\text { British Virgin } \\
\text { Islands }\end{array}$ & 30 & 32 & 153.0 & 49 & 34,246 & $37(2005)$ \\
\hline
\end{tabular}


Table 2. Cont.

\begin{tabular}{|c|c|c|c|c|c|c|c|}
\hline & \multirow{2}{*}{ Country } & \multicolumn{2}{|c|}{ Population (Thousands) $^{a}$} & \multirow{2}{*}{$\underset{\left(\mathrm{km}^{2}\right)}{\text { Land Area }}$} & \multirow{2}{*}{$\begin{array}{c}\text { Urban } \\
\text { Population } \\
\text { (UP) (\%) }\end{array}$} & \multirow{2}{*}{$\begin{array}{c}\text { GDP Per } \\
\text { Capita (US\$) }\end{array}$} & \multirow{2}{*}{$\begin{array}{c}\text { MSW } \\
\text { Collected } \\
\left(10^{3} \text { tons }\right) \mathrm{e}\end{array}$} \\
\hline & & 2019 & 2030 & & & & \\
\hline & $\begin{array}{l}\text { Cayman } \\
\text { Islands }\end{array}$ & 65 & 73 & 259.0 & 100 & 91,393 & nd \\
\hline & Cuba & 11,333 & 11,142 & $109,884.0$ & 78 & 9296 & $4888(2015)$ \\
\hline & Dominica & 72 & 73 & 750.0 & 71 & 5952 & $21(2005)$ \\
\hline & $\begin{array}{c}\text { Dominican } \\
\text { Republic }\end{array}$ & 10,739 & 11,770 & $48,442.0$ & 83 & 8282 & nd \\
\hline & Grenada & 112 & 116 & 348.5 & 37 & 10,809 & nd \\
\hline & Guadeloupe & 400 & 400 & 1628.0 & 100 & 27,000 & $262(2013)$ \\
\hline & Guyana & 783 & 822 & $214,969.0$ & 28 & 6609 & $111(2011)$ \\
\hline & Haiti & 11,263 & 12,733 & $27,750.0$ & 58 & 1272 & nd \\
\hline & Jamaica & 2948 & 3048 & $10,991.0$ & 57 & 5582 & $1464(2006)$ \\
\hline & Montserrat & 5 & 5 & 102.0 & 10 & 13,487 & nd \\
\hline & Puerto Rico & 2933 & 2905 & 9104.0 & 94 & 32,874 & nd \\
\hline & $\begin{array}{l}\text { Saint Kitts } \\
\text { and Nevis }\end{array}$ & 53 & 56 & 261.0 & 31 & 19,935 & nd \\
\hline & Saint Lucia & 183 & 189 & 617.0 & 19 & 11,611 & $72(2015)$ \\
\hline & $\begin{array}{l}\text { Saint Vincent } \\
\text { and the } \\
\text { Grenadines }\end{array}$ & 111 & 113 & 389.0 & 53 & 7458 & 38 (2002) \\
\hline & Suriname & 581 & 632 & $163,820.0$ & 19 & 6491 & 205 (2015) \\
\hline & $\begin{array}{c}\text { Trinidad and } \\
\text { Tobago }\end{array}$ & 1395 & 1413 & 5131.0 & 54 & 17,398 & 425 (2002) \\
\hline & $\begin{array}{l}\text { US Virgin } \\
\text { Islands }\end{array}$ & 105 & 101 & 346.4 & 97 & 37,233 & nd \\
\hline \multirow{17}{*}{$\begin{array}{l}\text { PACIFIC (20): } \\
\text { UP (56.5\%) }\end{array}$} & $\begin{array}{c}\text { American } \\
\text { Samoa }\end{array}$ & 55 & 55 & 199.0 & 88 & 11,467 & nd \\
\hline & Cook Islands & 18 & 18 & 236.7 & 77 & 21,603 & nd \\
\hline & Fiji & 890 & 966 & $18,274.0$ & 58 & 6176 & nd \\
\hline & $\begin{array}{c}\text { French } \\
\text { Polynesia }\end{array}$ & 279 & 297 & 4167.0 & 62 & 14,324 & 125 (2013) \\
\hline & Guam & 167 & 181 & 549.0 & 96 & 35,712 & nd \\
\hline & Kiribati & 118 & 139 & 811.0 & 56 & 1655 & nd \\
\hline & $\begin{array}{l}\text { Marshall } \\
\text { Islands }\end{array}$ & 59 & 65 & 181.3 & 79 & 3788 & $26(2007)$ \\
\hline & $\begin{array}{l}\text { Federated } \\
\text { States of } \\
\text { Micronesia }\end{array}$ & 114 & 127 & 702.0 & 23 & 3568 & nd \\
\hline & Nauru & 11 & 11 & 21.0 & 100 & 9397 & nd \\
\hline & $\begin{array}{c}\text { New } \\
\text { Caledonia }\end{array}$ & 283 & 311 & 18,575 & 71 & 12,580 & nd \\
\hline & Niue & 2 & 2 & 261.5 & 47 & 15,586 & nd \\
\hline & $\begin{array}{l}\text { Northern } \\
\text { Mariana } \\
\text { Islands }\end{array}$ & 57 & 61 & 477.0 & 91 & 23,257 & nd \\
\hline & Palau & 18 & 18 & 459.0 & 81 & 14,902 & nd \\
\hline & $\begin{array}{c}\text { Papua New } \\
\text { Guinea }\end{array}$ & 8776 & 10,709 & $462,840.0$ & 13 & 2829 & nd \\
\hline & Samoa & 197 & 220 & 2842.0 & 18 & 4324 & $5(2015)$ \\
\hline & $\begin{array}{l}\text { Solomon } \\
\text { Islands }\end{array}$ & 670 & 865 & $28,400.0$ & 25 & 2374 & nd \\
\hline & Timor-Leste & 1293 & 1574 & $15,007.0$ & 31 & 1560 & nd \\
\hline
\end{tabular}


Table 2. Cont.

\begin{tabular}{|c|c|c|c|c|c|c|c|}
\hline & \multirow{2}{*}{ Country } & \multicolumn{2}{|c|}{ Population (Thousands) ${ }^{a}$} & \multirow{2}{*}{$\underset{\left(\mathrm{km}^{2}\right)}{\text { Land Area }}$} & \multirow{2}{*}{$\begin{array}{c}\text { Urban } \\
\text { Population } \\
(\text { UP) }(\%)\end{array}$} & \multirow{2}{*}{$\begin{array}{c}\text { GDP Per } \\
\text { Capita (US\$) d }\end{array}$} & \multirow{2}{*}{$\begin{array}{c}\text { MSW } \\
\text { Collected } \\
\left(10^{3} \text { tons) }\right.\end{array}$} \\
\hline & & 2019 & 2030 & & & & \\
\hline & Tonga & 104 & 116 & 748.5 & 24 & 4903 & nd \\
\hline & Tuvalu & 12 & 13 & 26.0 & 64 & 4059 & nd \\
\hline & Vanuatu & 300 & 383 & $12,189.0$ & 26 & 3116 & nd \\
\hline \multirow{9}{*}{$\begin{array}{l}\text { AIMS (9): UP } \\
(60.6 \%)\end{array}$} & Bahrain & 1641 & 2013 & 765.3 & 90 & 23,504 & nd \\
\hline & $\begin{array}{c}\text { Cape Verde } \\
\text { (Cabo Verde) }\end{array}$ & 550 & 610 & 4033.0 & 67 & 3604 & $146(2015)$ \\
\hline & Comoros & 851 & 1063 & 1862.0 & 30 & 1370 & nd \\
\hline & $\begin{array}{l}\text { Guinea- } \\
\text { Bissau }\end{array}$ & 1921 & 2461 & $36,125.0$ & 44 & 697 & nd \\
\hline & Maldives & 531 & 519 & 300.0 & 41 & 10,626 & $325(2014)$ \\
\hline & Mauritius & 1270 & 1274 & 2040.0 & 41 & 11,099 & $486(2015)$ \\
\hline & $\begin{array}{c}\text { São Tomé } \\
\text { and Principe }\end{array}$ & 215 & 268 & 1001.0 & 74 & 1947 & nd \\
\hline & Seychelles & 98 & 103 & 458.4 & 58 & 17,748 & nd \\
\hline & Singapore & 5804 & 6262 & 728.6 & 100 & 65,233 & 7668 (2015) \\
\hline \multicolumn{2}{|c|}{ Total/Average } & 70,699 & 74,694 & na & 58.4 & 15,154 & nd \\
\hline
\end{tabular}

Source: Authors based on ${ }^{\mathrm{a}}$ United Nations (UN) [31] ${ }^{\mathrm{b}}$ Worlddata [32] ${ }^{\mathrm{c}} \mathrm{UN}$ [33], ${ }^{\mathrm{d}}$ UN [34], World Bank [35], ${ }^{\mathrm{e}}$ UN [36]-numbers between brackets refer to year in which data were collected. Legend: nd-no data, na-not applicable.

\section{Research Findings}

\subsection{Principles of Waste Management Strategy for SIDS}

As stated by the European Commission, waste production prevention must be conducted in the first place [37]. According to the European strategy, which is also recommended for SIDSs and elsewhere, the following priority should be defined: (1) prevention/reduction of waste production, (2) reuse for the same or another purpose, (3) recycling, (4) energy recovery, and (5) disposal (landfilling). We will present the description and relevance of each level of this hierarchy for SIDSs later in this section (refer to Zhang et al. [38] for general consideration on the hierarchy). Preference should be given to energy recovery at the expense of landfilling because organic matter (OM) (i.e., biologically degradable waste) should be subjected to biological processes (e.g., anaerobic digestion to produce, for instance, biogas for energy), and combustible waste-with non-biodegradable matter and low moisture content-can go through thermal processing.

Owing to obvious similarities (e.g., high population and urbanization density, dominance of third sector-service), the Manhattan [9] example might be used for benchmarking purposes to develop waste reuse, recycling, and WtE programs at the expense of landfilling practice in SIDSs. Furthermore, the environmental sensitivity of SIDSs and their economic dependence on tourism are factors that make Environmental Impact Assessment (EIA) of MSW infrastructures of critical importance to define the feasibility and reliability of WtE industries. For this purpose, the European Commission delivered a guideline on integrated pollution prevention and control [39] that can be adapted to the SIDS reality.

MSW and domestic wastewater are suitable for WtE industry (Figure 2) and usually comprise the following technologies: waste incineration power generation; food waste biogas power generation; waste oil derived biodiesel; organic wastewater biogas power generation; and on-farm livestock manure biogas power generation. 


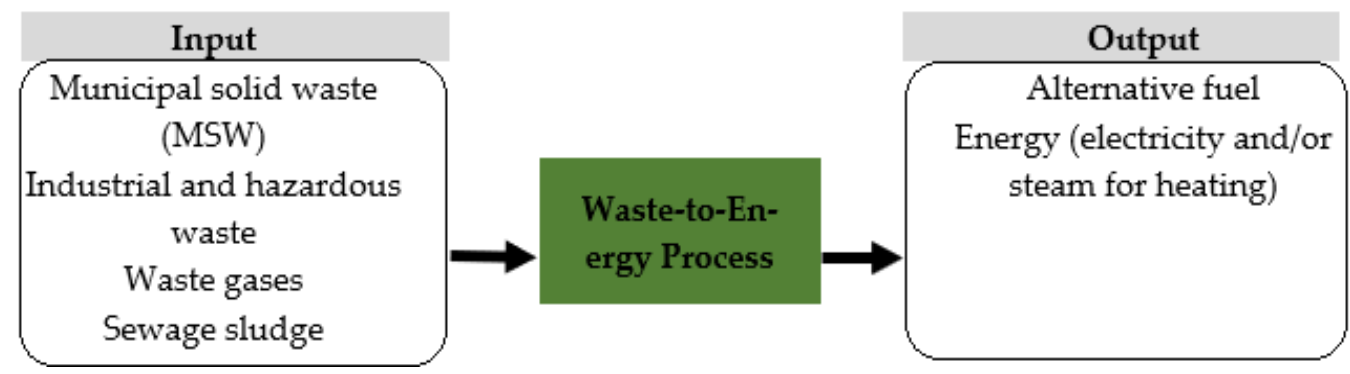

Figure 2. Input (waste) vs. output (alternative fuel and energy) of WtE industry.

MSW generally includes fractions of paper, plastic, rubber, fabrics, food waste, wood and yard trimmings, cotton, and leather (Table 3).

Table 3. MSW composition in SIDS.

\begin{tabular}{ccc}
\hline Type of Waste & Range of Variation-SIDS (\%) & Average Proportion-SIDS (\%) \\
\hline Organics & $41-48$ & 44 \\
\hline Paper & $11-17$ & 16 \\
\hline Plastics & $12-14$ & 13 \\
\hline Metals & $7-10$ & 8 \\
\hline Glass & $2-7$ & 6 \\
\hline Others & $12-20$ & 13
\end{tabular}

Note: MSW ranges from $0.82 \mathrm{~kg} /$ capita/day in Pacific to $1.61 \mathrm{~kg} /$ capita/day in Caribbean SIDSs. Source: authors based on Mohee et al. [17].

The predominance of the organics fraction $(44 \%)$ and recyclables (43\%: paper, plastics, metals, and glass) in MSW of SIDSs (Table 3) suggests that, among the available techniques (recycling, composting, anaerobic digestion, thermochemical processes, and landfilling), composting and anaerobic digestion can be applied to manage the organics, and recyclables can be used to produce energy (WtE) and also new products via recycling. However, recycling requires stakeholder maturity (willingness to perform adequate separation at home) regarding the waste management chain, since it entails the separation, collection, and preparation of waste materials to allow conversion into another material.

As tourism is of the utmost importance for SIDSs' economies [29,30], particular efforts should be done, in terms of environmental governance, to encourage relevant stakeholders (e.g., hotel, and other tourism-related installation/service) to implement environmental management systems according to the ISO 14,000 family of standards (see Mata-Lima et al. [6] for more information on ISO 14,000 in developing areas) as a way to enforce waste prevention, reuse, and recycling (depends on waste separation at the source).

It is imperative to increase the share of renewable sources in gross final consumption of energy in SIDS, which is currently dominated by fossil fuel [16,40]. Taking African/Indian Ocean SIDSs as examples, it is possible to understand that the situation is of major concern in most of countries (Table 4), since fossil fuel is the main source of energy.

Table 4. Main sources of energy in African/Indian Ocean SIDSs.

\begin{tabular}{cccccccc}
\hline & \multicolumn{7}{c}{ Countries } \\
\hline $\begin{array}{c}\text { Share of } \\
\text { Energy (\%) }\end{array}$ & Comoros & Cabo Verde & Mauritius & Guinea-Bissau & Maldives & $\begin{array}{c}\text { São Tomé } \\
\text { and Principe }\end{array}$ & Seychelles \\
\hline Fossil fuel & 34 & 35 & 72 & 100 & 100 & 74 & 100 \\
\hline
\end{tabular}

Source: Authors according to data of the International Energy Agency (IEA) treated by Wolf et al. [16]. 
The adoption of WtE technologies is an opportunity to increase the proportion of renewable energy in SIDSs, and decision making should consider economical solutions (e.g., incineration, anaerobic digestion of organic waste) that minimize the environmental issues.

\subsection{Waste to Energy Technologies (WtE) Outlook}

SIDSs are experiencing tourism growth (the only means of economic development in several SIDS) and massive urbanization (Table 2, and Figure 3), and they are facing difficulties with respect to municipal solid waste (MSW, comprises household and commercial wastes) management. The high average density registered in SIDSs (147, 231, and 1509 inhab $/ \mathrm{km}^{2}$, respectively in Pacific, Caribbean, and AIMS) makes it clear that the strategic management of MSW considering regional characteristics is mandatory. Therefore, $\mathrm{WtE}$ can play an important role by reducing waste disposal and increasing urban energy security, since it is designed for waste processing (treatment) and to produce energy and alternative fuel.

In spite of the contribution of WtE to reduce EF and greenhouse gases, they still have some environmental concerns, and the emissions typically include very low concentrations (when compared to European Union and USEPA standards) of nitrogen oxides $\left(\mathrm{NO}_{\mathrm{x}}\right)$, sulfur oxides $\left(\mathrm{SO}_{\mathrm{x}}\right)$, carbon monoxide $(\mathrm{CO})$, particulate matter $(\mathrm{PM})$, heavy metals (mainly $\mathrm{Hg}$ ), total organic carbon (TOC), and dioxins $[9,19,41]$, although landfilling produces higher emissions [42]. Hence, the strategy for SIDSs should consider reduced landfilling while increasing recycling, composting, biological process, and thermochemical processing (see description in Table 5). This work does not consider physicochemical pathways, such as transesterification, in which organic wastes are converted to energy by the use of chemical agents [43].
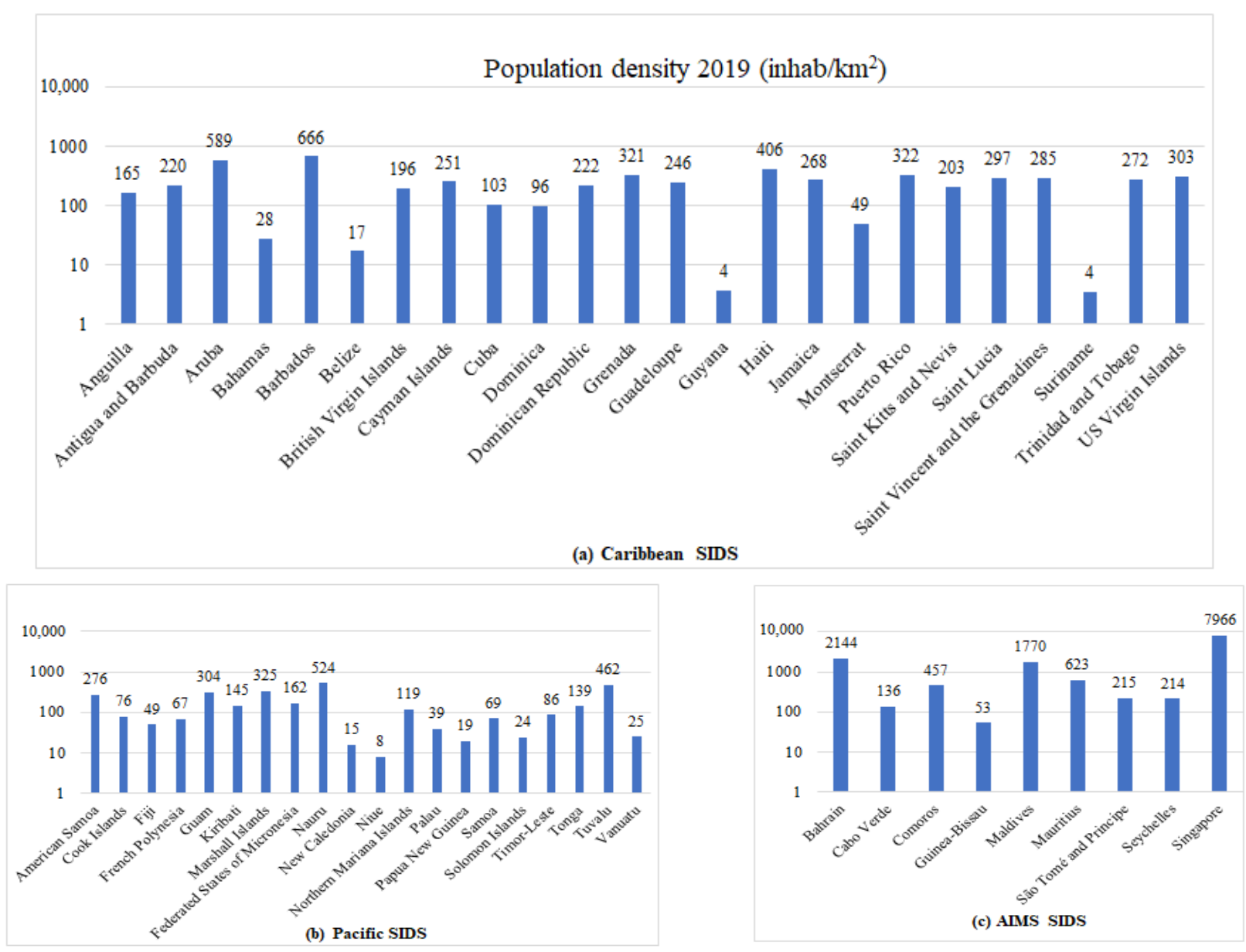

Figure 3. Population density (inhabitants $/ \mathrm{km}^{2}$ ) in SIDSs in 2019. Source: authors based on Table 2. 
Table 5. Brief description of waste management technologies regarding energy recovery.

\section{Waste Management}

Technology (WMT)

Brief Description

Represents the ultimate disposal of waste and is the least desired option. Landfilling is economically relatively cheap compared to other waste management technologies, but it is environmentally expensive for SIDSs due to land scarcity and high MSW production, particularly when the tourism industry is relevant. This technique is of major concern because it does not consider the complete lifespan of

Landfilling recyclable materials, although this is the main waste management technology adopted worldwide and in SIDSs, where most of them are not sanitary (i.e., uncontrolled dumping wastes without leachate management and gas collection). The high level of moisture as well as the proportion of organic matter in MSW of SIDSs (Table 4) accelerate the process of landfill gas production, so existing landfills can be easily retrofitted (with low cost) to capture biogas to produce electricity.

The process of separating, collecting, and preparing waste to be reprocessed or remanufactured into another material. This option extends the life cycle of materials by transforming waste into valuable products (with reduced energy and water consumption, as well less air pollution) or provides inputs for WtE technologies, but successful recycling depends on stakeholders (e.g., community, decision-maker) education and engagement to assure the quality of separation as well as costs of collection and transport to processing units. High value-added recycling is the key to a circular economy.

Corresponds to biological degradation of organic wastes in the presence of oxygen to produce a compost that can be safely used as a soil conditioner. This technology is highly relevant to manage the organic fraction (biologically decomposable substances), which represents a high proportion of MSW in SIDSs (Table 4). With respect to location, densely populated areas should be avoided because the odor impact

can reach up to $200 \mathrm{~m}$. Approximately $20-25 \%$ of the initial amount requires landfill disposal.

Composting

BPs can be both aerobic and anaerobic. The most common is anaerobic digestion (AD), which stands for biological decomposition of organic materials in the absence of oxygen to produce biogas $\left(\mathrm{CH}_{4}\right.$ and $\left.\mathrm{CO}_{2}\right)$ and a digestate of high nutrient value. This technology of waste management is recommendable for SIDSs, Biological processes because the organic fraction of MSW reaches $44 \%$. AD has been the mechanism of several biogas plants in (BPs):

anaerobic digestion,

fermentation
SIDSs since the 1940s. Biogas has been produced via application of AD to treat agricultural wastes,

domestic wastewaters, and animal manures. Regarding fermentation processes, neither bio-hydrogen or bio-ethanol are commonly used to produce energy in SIDSs yet, whereas the latter is more present. It is important to stress that fermentation processes are not yet applied to MSW, but rather to sugarcane, molasses, coconut, etc. It is worth mention that BP can be combined with compost production (e.g., for agricultural use), or incineration of the bio-dried fraction, or even landfilling of the stabilized residue.
Application to Energy Production

\section{References}

Can include electricity production from the landfill biogas but does not deserve priority in SIDSs or elsewhere (see

Table 3-environmental impacts of WMT).

Recyclables are used to foster the production energy through thermochemical processes, so that recycling is important due to extensive pre-processing (to eliminate low calorie materials) that is required when the efficiency of thermochemical processes is to

be increased.

$\mathrm{BP}$ is used with the following main purposes: minimization of landfilled masses and volume, drying of high calorific fractions to use as fuel, collection of the produced biogas to produce electricity and/or heat. 
Table 5. Cont.

Waste Management

Technology (WMT)

Brief Description

Application to Energy Production

References

The process lowers the waste volume (reduce its initial volume by $90 \%$ and its weight by $75 \%$ when incinerated Clausen and Pretz) and utilizes the chemically bounded energy in the waste (i.e., heat and/or electric power, and alternative fuels are produced via thermal processing). It also promotes destruction of hazardous materials that can represent a significant environmental and public health risk. Among the thermochemical processes, incineration (or combustion) is the most popular in SIDSs and represents the thermal degradation and decomposition of waste materials or biomasses in the presence of oxygen to produce $\mathrm{CO}_{2}, \mathrm{H}_{2} \mathrm{O}$, and heat at a temperature of $800-1000{ }^{\circ} \mathrm{C}$. Incineration with energy recovery might be considered as way to avoid costs associated with conventional technologies (e.g., burning of fossil fuels)

With respect to the waste category, it is important to highlight that hospital waste is rather more

appropriate than domestic waste because the high moisture content of the latter leads to low energy

output. Singapore is where incineration is more significant, with $41 \%$ of the wastes incinerated to produce necessary heat that contributes to $2-3 \%$ of the total electricity requirement of the country. Incineration with energy recovery is also the most common in European member states-EU28 Eurostat Municipal

Waste Statistics. Nevertheless, this technology has environmental concerns such as the emission of

harmful pollutants and the production of ash that is usually disposed of in landfills. It would be

Thermochemical processes:

Incineration

Gasification

Pyrolysis

列 Kalbe and Simon and Aracil et al. In Luxembourg botto capacity by $31 \%$ Bruno, $\mathrm{M}$. et al. tires, used oil, biomass, agricultural wastes,

Gasification is the partial combustion of biomass (e.g., agricultural and forest wastes, and surplus of coconut) at about $800-1000{ }^{\circ} \mathrm{C}$ to form a combustible gas mixture. The waste is converted into a product which is gasified for steam and electricity production. This technology can contribute to mitigate issues that arise owing to the lack of capacity to afford a landfill, as well as emissions of harmful pollutants from incineration. Aracil et al. found that gasification yields lower GHG emissions than incineration, and that gasification with a fluidized bed gasifier (FBG) with an internal combustion engine (ICE) is more profitable due to higher electrical efficiency but recommended a fluidized bed gasifier (FBG) with organic Rankine cycle (ORC) as a better option in the short-term for landfill-dominated countries due to its higher technical reliability.

Pyrolysis is the breakdown of organic materials in the absence of oxygen at around $400-1000{ }^{\circ} \mathrm{C}$, resulting in liquid (bio-oil), gaseous, and solid (charcoal) products. This technology is less used in SIDS but has been applied to rice husk, wood (to produce charcoal), and scrap tires.

Preferably for combustible MSW with non-biodegradable matter and low moisture content. It is reported that hospital wastes, and wood has been used to produce energy

via thermochemical processes in SIDS.

Among factors that contribute positively to

WtE performance are waste composition

(low organic matter), effectiveness of

recycling (relies on stakeholder

engagement), and low moisture content of

the refuse, though the pre-processing

demand can be very low at the expense of some efficiency decrease.

There is consolidated knowledge concerning incineration, since it is the prominent

disposal method in Western Europe, Japan, and South Korea. There are studies

reporting efficiency of WtE plants from 21.7

to $30 \%$ Murer et al. and 12.1 to $21.6 \%$

CEWEP Energy Report III, and power generation ranging from 0.3 to

$0.7 \mathrm{MWh} /$ ton MSW, respectively, for

combined heat and power and for electricity recovery plants Tabasová et al . 
Valerio [49] observed that for well source separated and clean fraction materials, recycling exerted lower environmental impacts than incineration, although when thermochemical processes (e.g., incineration with energy recovery) are considered to produce electricity in substitution of fossil fuel (coal and oil) power plants, the environmental and economic benefits are significant, as SIDSs exhibit an average MSW production per capita as high as developed OECD countries (Figure 4).

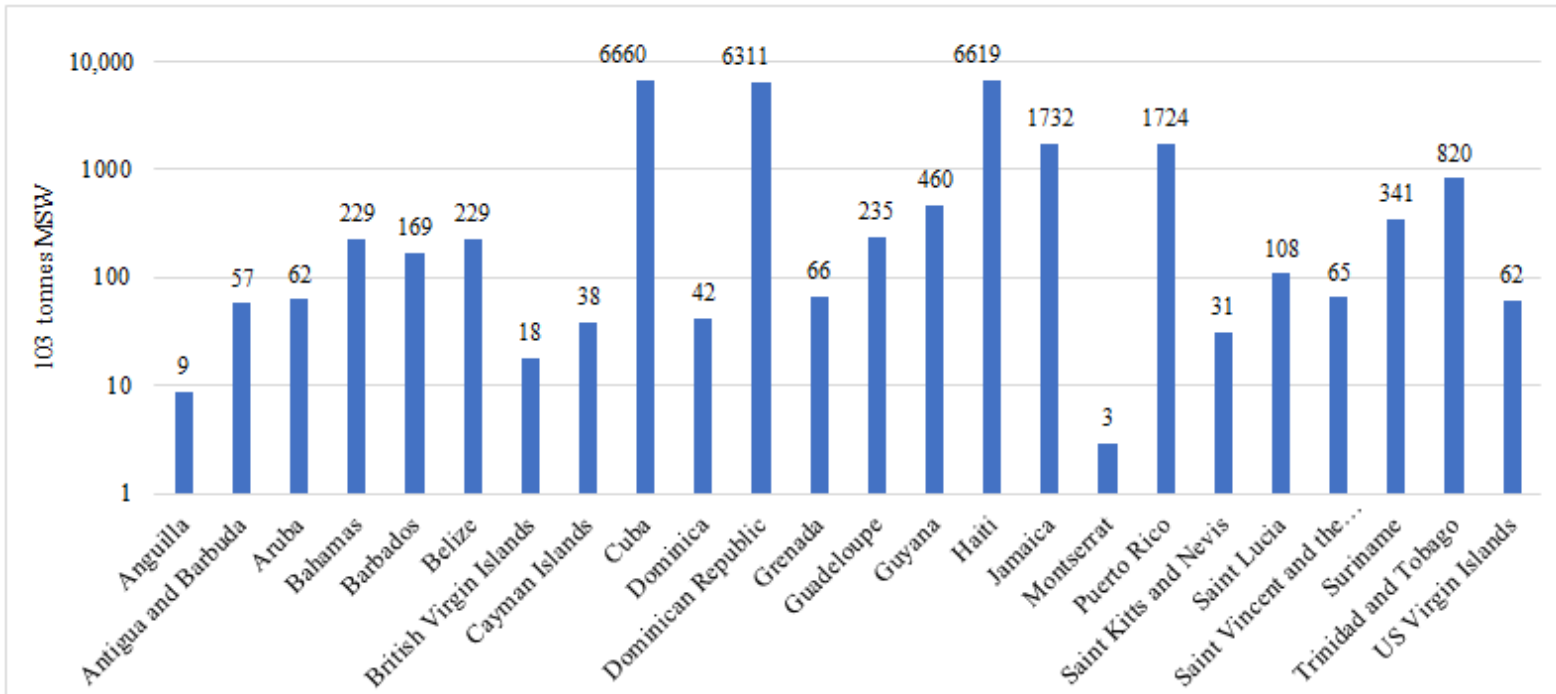

(a) Caribbean SIDS
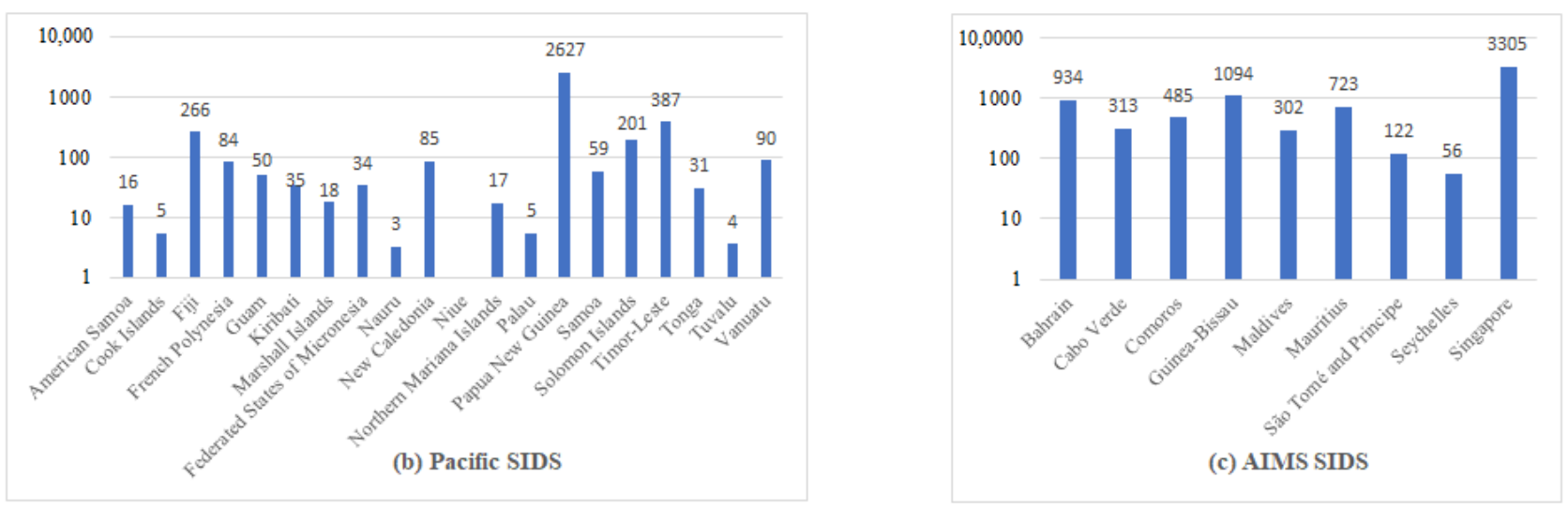

Figure 4. Estimation of MSW production in SIDSs based on average production per capita $(1.61,0.82$, and $1.56 \mathrm{~kg} / \mathrm{per}$ capita/day, respectively in Caribbean, Pacific, and AIMS SIDSs [17]) and 2019 population displayed in Table 2. Source: authors based on data from [17] and Table 2.

The results depicted in Figure 4 show that SIDSs produce enough MSW to justify the installation of either small (32-227 tons/day) or large (>227 tons/day) WtE facilities, depending on the country considered, to prevent the environmental impacts of landfilling (see Table 6) and fossil fuel power plants. Taking the country with lower MSW production among SIDSs (Tuvalu with 3,600,000 tons/year, Table 2) and considering that 30 million tons require 3,000,000 $\mathrm{m}^{2}$ of land for landfilling (Table 7), Tuvalu would require $41.5 \%$ $\left(10,800,000 \mathrm{~m}^{2}\right)$ of its total land area $\left(26 \mathrm{~km}^{2}\right)$ to dispose 30 years of waste. If, on the other hand, SIDSs decide to combust $50 \%$ of their MSW in incineration plants with energy recovery, it is possible to produce significant power capacity (Figure 5), considering that modern incineration plants produce $537.28 \mathrm{kWh}$ of electricity for each 1 metric ton of MSW in Portugal [58]. Psomopoulos et al. [9] reported a similar value for USA, namely $600 \mathrm{kWh} /$ tone of MSW. 

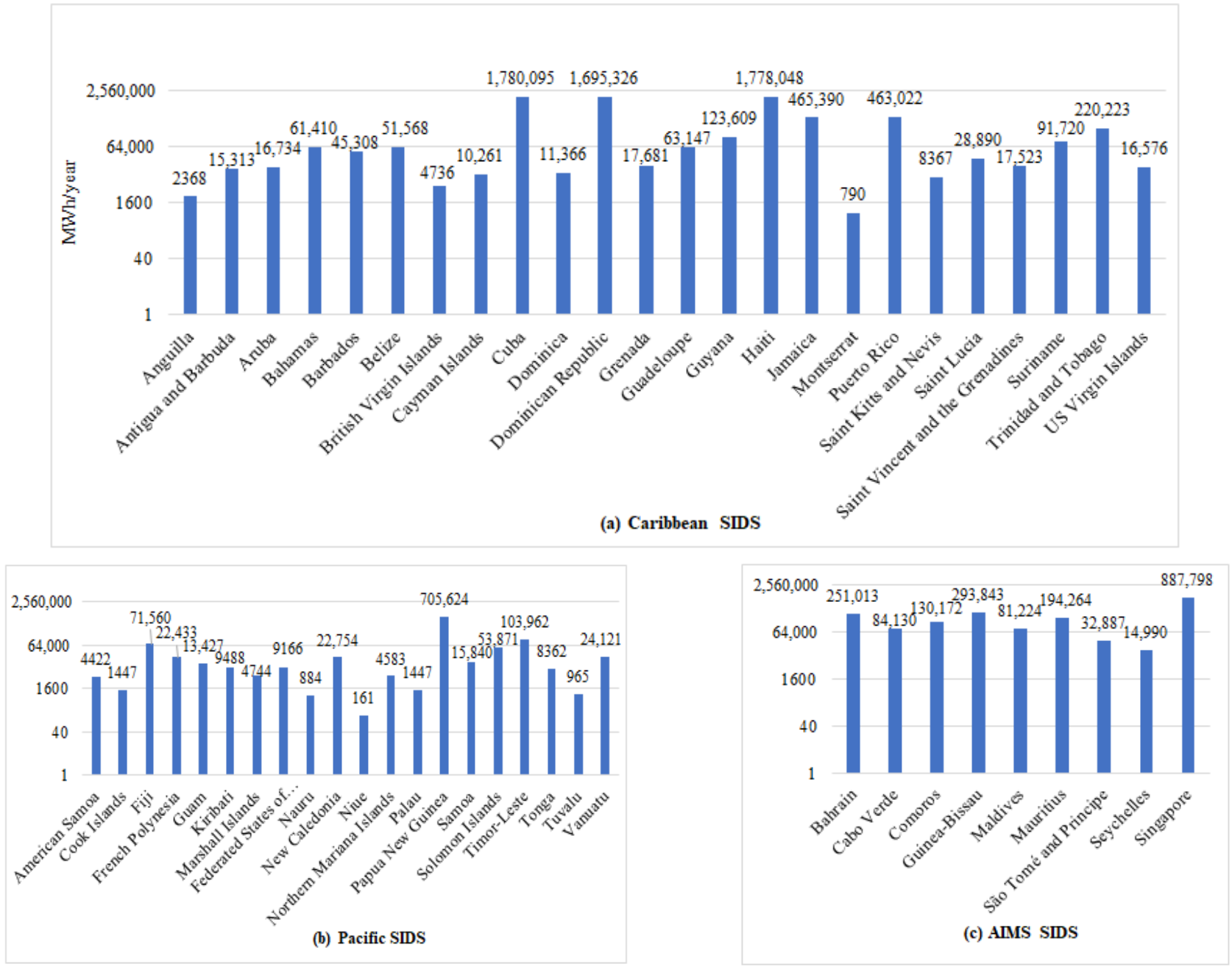

Figure 5. Estimated power generation capacity (MWh/year) for incineration of $50 \%$ of total waste generated in SIDS. The values displayed in the figure correspond to countries with minimum and maximum MWh. Source: authors based on data from Figure 4 and [58].

The results presented in Figure 5, regarding the use of 50\% of MSW to produce electricity via incineration with energy recovery, indicate that $\mathrm{WtE}$ technologies can play an important role as renewable energy sources to reduce the proportion of non-renewables (e.g., fuel oil, coal) in the electricity mix in SIDSs. For instance, Mauritius (AIMS SIDS) consumes annually almost $2800 \mathrm{GWh}$ of electricity with fossil energy, representing a share of $72 \%$ in electricity production $[40,59]$ but can produce $194.3 \mathrm{GWh}$ from $50 \%$ of MSW as estimated based in 2019 data (Table 2, Figure 4). In Caribbean SIDS, Belize is the only country where renewable energy (RE) predominates in the electricity mix, with a share of $65 \%$ (in 2012) and a target of $89 \%$ by 2033 [60]. Some countries set in 2012 the ambitious targets of $100 \%$ (Dominica, Grenada, Montserrat), 90\% (Guyana), and 46\% (Haiti) to be achieved before 2030 [60], representing a dramatic change that varied from 31.5 (for Haiti) to $100 \%$ (for Montserrat) of the share in the electricity mix. 
Table 6. Main environmental aspects and impacts of waste-to-energy (thermochemical process).

\begin{tabular}{|c|c|c|c|c|c|c|c|c|c|c|c|c|c|c|}
\hline \multicolumn{7}{|c|}{ Environmental Aspects } & \multicolumn{8}{|c|}{ Environmental Impacts } \\
\hline $\begin{array}{l}\text { Emission } \\
\text { to air }\end{array}$ & $\begin{array}{l}\text { Discharge } \\
\text { to water }\end{array}$ & $\begin{array}{l}\text { Discharge } \\
\text { into soil }\end{array}$ & Noise & $\begin{array}{l}\text { Production of } \\
\text { bottom ash (can } \\
\text { be used in } \\
\text { construction } \\
\text { sector or } \\
\text { landfilled) }\end{array}$ & $\begin{array}{l}\text { Resources } \\
\text { consump- } \\
\text { tion (land } \\
\text { occupation) }\end{array}$ & $\begin{array}{l}\text { Production } \\
\text { of photo- } \\
\text { oxidants }\end{array}$ & $\begin{array}{l}\text { Atmospheric } \\
\text { warming } \\
\text { (e.g., } \mathrm{CO}_{2} \\
\left.\text { and } \mathrm{CH}_{4}\right)\end{array}$ & $\begin{array}{l}\text { Ecosystem } \\
\text { and biodi- } \\
\text { versity } \\
\text { degrada- } \\
\text { tion }\end{array}$ & $\begin{array}{l}\text { Human } \\
\text { toxicity }\end{array}$ & $\begin{array}{l}\text { Ecological } \\
\text { footprint }\end{array}$ & $\begin{array}{l}\text { Rain } \\
\text { acidifi- } \\
\text { cation }\end{array}$ & $\begin{array}{c}\text { Water } \\
\text { eutrophication }\end{array}$ & $\begin{array}{l}\text { Increase } \\
\text { of temper- } \\
\text { ature of } \\
\text { receiving } \\
\text { water }\end{array}$ & $\begin{array}{l}\text { Job } \\
\text { creation } \\
\text { (including } \\
\text { qualified) }\end{array}$ \\
\hline$\downarrow$ & $\downarrow$ & $\downarrow$ & $\downarrow$ & $\downarrow$ & $\downarrow$ & $\uparrow$ & $\downarrow$ & $\downarrow$ & $\downarrow$ & $\downarrow$ & $\downarrow$ & $\downarrow$ & $\uparrow$ & $\uparrow$ \\
\hline
\end{tabular}

Source: authors based on Psomopoulos et al. [9], Cucchiella et al. [19], AlQattan et al. [46], Tabasová et al. [48], Bruno et al. [51], Sewak et al. [61], Aryampa et al. [62]. 
It is worth mentioning that the higher the urban population and density, the higher the relevance of WtE technology for MSW management, which makes AIMS the worst regionamong SIDSs - to adopt landfilling practices. Despite this situation, some countries of AIMS are mainly dependent on fossil fuels (see Table 4) to produce electricity, so that attention should be given to $\mathrm{WtE}$ technologies to simultaneously increase the share or RE in electricity mix and reduce de ecological footprint (EF) due to landfilling (because it implies land occupancy and considerable GHG emissions; see Table 5).

Among the environmental aspects (EA) and impacts (EI) included in Table 6, production of photo-oxidants (which accelerate organic contaminant degradation in surface water) and job creation are increased $(\uparrow)$ by $\mathrm{WtE}$ technologies and are considered positives. The remaining list of EA and EI are mitigated $(\downarrow)$ by adopting WtE, except the increase of temperature of receiving water bodies, which does not occur in the case of landfilling.

Bearing in mind the fact that landfilling is the main destination of MSW in SIDSs and that recycling is scarce (e.g., due to lack of education and sensitization of stakeholder, and low quantity of recyclables that constrains the economy of scale), production of energy from biogas (methane $\left(\mathrm{CH}_{4}\right)$ and carbon dioxide $\left(\mathrm{CO}_{2}\right)$ ) can be assigned to landfills. Furthermore, anaerobic digestion is also an alternative for energy production from both MSW and sludge from wastewater plants.

Considering the existing technologies (Table 5), it is important to stress that the most appropriate technology to be adopted in each situation depends on waste composition $[48,63]$. All the WtE technologies (Table 5) have advantages and drawbacks according to MSW characteristics (quantity, and composition), community awareness (that influences the recycling), and local human resources qualifications to deal with the complexity of the processes, even though WtE can reduces the dependence of SIDSs from the importing of petroleum products used in conventional thermoelectric plants.

Therefore, the two widely adopted WtE technologies are as follows $[1,48,64,65]$ : (1) technologies regarding biogas power generation based on biological processes, which occur by fermentation, and mainly anaerobic digestion (in this process microorganisms break down organic biodegradable material in the absence of oxygen whilst biogas is produced for energy purpose); and (2) waste incineration power generation, which is appropriate for combustible MSW with non-biodegradable matter and low moisture content (in this process the organic matter in waste reacts with excess oxygen in a combustion process in a furnace, from which the generated heat can be utilized for power generation). There are other WtE technologies such as landfill gas recovery, gasification, pyrolysis, and hydrolysis that are used in developed countries on a smaller scale $[1,48,66]$.

The two widely-used WtE technologies (biological and thermochemical processes) have some drawbacks in the SIDS context (e.g., waste must be correctly separated at the source, but this is not a practice in SIDSs) which can be a real impairment in developing countries, particularly in those with lower levels of social capital (i.e., the ability of organizations and individual to be organized in networks to make possible the collective goals).

Table 7. Main WtE advantages and disadvantages.

\section{Advantages}

Reduction of dependence on fossil energy.

The required land is quite small (WtE plant processing 1 million tons/year requires less than 100,000 $\mathrm{m}^{2}$ of land, including landscaping and auxiliary buildings). On the other hand, to dispose this amount of waste in a landfill for 30 years (lifetime of WtE plant) 3,000,000 $\mathrm{m}^{2}$ of land area is necessary [9].

$\mathrm{WtE}$ can vary from small (32-227 tons/day) to large facilities ( $>227$ tons/day).

Mitigation of GHG emission and so global warming, since compared to landfilling, WtE reduces pollutant emissions of MSW by eliminating $\mathrm{CH} 4$ and offsetting emissions from fossil fuel power plants.

Enhancement of urban energy security by introducing an alternative source. Purification of waste disposal.

Opportunity to use bottom ash in the construction industry. Maximization of energy contained in flue gas.

Minimization of the volume of waste intended for landfilling. For instance, incineration of MSW can reduce its initial volume by $90 \%$ and its weight by $75 \%$. Incineration prevents aqueous and gaseous pollution related to landfilling. 
Table 7. Cont.

Advantages

Transportation of waste from the source point to WtE plants requires less logistic cost due to low distances.

Despite the higher cost of the WtE process compared to landfilling, it is still the best option due to several reasons such as reduction of ecological and carbon footprints in SIDSs.

Cucchiella et al. [19] observed that compared to other renewable energy sources (e.g., solar, geothermal, biomass, and hydro), energy recovery from MSW exhibits lower unit cost $(\$ / \mathrm{kWh})$ in parallel with wind energy.

Regarding $\mathrm{CO}_{2}$ emissions per kWh of electricity, MSW is also less polluting than coal, oil, and natural gas, as reported by the US Environmental Protection Agency [9,19].

Disadvantages

WtE industries still produce some emissions to the environment (e.g., incineration: $\mathrm{CO}_{2}, \mathrm{NO}_{\mathrm{x}}, \mathrm{SO}_{\mathrm{x}}$, heavy metal vaporization-Cu, $\mathrm{Pb}, \mathrm{Hg}, \mathrm{Cd})$, but there are technologies to control the emissions.

Though on a small scale, thermal processing entails concerns on the generation of emissions in flue gas, presence of hazardous substances in the ash, and pollution of water used in the incineration process.

Thermal processing usually requires pre-treatment, which involves sorting (e.g., light fraction-paper, plastic; heavy fraction-biologically decomposable substances that can be processed further by composting or anaerobic fermentation) and disintegration of waste, since MSW is commonly very heterogeneous, especially in regions with lack of community awareness.

Source: the authors based on Song et al. [1], Psomopoulos et al. [9], Cucchiella et al. [19], Tabasová et al. [48], Bruno et al. [51], Tozlu et al. [67], Cheng and Hu [68], Dvorák et al. [69], Gohlke et al. [70], Neehaul et al. [71].

\subsection{Challenges and Barriers to Sustainable Waste Management (SWM) in SIDS}

The increase of waste production as a consequence of rising gross domestic product (GDP), increasing human development index (HDI), population (and tourism) growth, and limited land area to afford a waste production rate like highly developed OECD countries unless landfilling is significantly reduced (e.g., a target of 10\% as established by European union would be appropriate) are among the main challenges to face.

There are other difficulties that practical experience has shown constitute persistent barriers to sustainable waste management. It is worth highlighting that the attractiveness of low investment in landfilling, and lack of population knowledge and engagement to guarantee extensive recycling, which is essential to increase the life cycle of products (i.e., circular economy), as well as electrical efficiency of WtE technologies represents barriers to accomplish sustainable waste management. Additionally, as the major portion of waste in SIDSs is disposed in open dumps and in inappropriate/uncontrolled landfills, there are not human resources with expertise in best management practices. Table 7 synthesizes some advantages and disadvantages of $\mathrm{WtE}$ technologies.

\section{Conclusions and Recommendations}

As economic growth is energy intensive, it is of utmost importance to highlight that the transition to renewable energy systems is among the main SIDS challenges to reduce the dependence on fossil energy and the vulnerability to oil price shock, and to support sustainable livelihoods. Access to secure energy is vital to guarantee education, utility services, and others sustainable development goals that are energy-dependent. Considering the higher cost of fossil energy and the high concentration of population in urban areas (Table 2, Figure 3) leading to significant amount of wastes (Figure 4) available for energy recovery in SIDSs, the adoption of WtE technologies will make a significant contribution to urban energy supply and sustainable waste management.

WtE facilities for MSW management can serve more than 70 million people in SIDSs (Table 2). Hence, there is a clear opportunity to adopt socioeconomic and environmental policies that induce the penetration of innovative technologies focused on reducing waste production and enhancing recycling to align SIDSs with developed OECD countries. The higher the urban population and density, the higher the relevance of WtE technologies for MSW management, which makes AIMS (with average density of $1509 \mathrm{inhab} / \mathrm{km}^{2}$ ) the worst region-among SIDSs-to adopt landfilling practices. 
The feasibility of WtE technologies was demonstrated using 50\% annual MSW of each SIDS to estimate the potential power generation capacity (MWh). Furthermore, only 3\% of the landfill area (see advantages in Table 7) is necessary for buildings and landscaping associated with a WtE plant able to treat 1 million tons of MSW, considering a 30 year lifespan. Additionally, incineration with energy recovery benefits from high penetration worldwide and affordable cost among thermochemical processes.

Among the reasons for the absence of investments in $\mathrm{WtE}$ facilities in SIDSs is naturally the low cost associated with landfilling, particularly when most waste is disposed in either uncontrolled landfills or open dumps. Therefore, to change the current situation, we recommend that attention should be given to the fact that $\mathrm{WtE}$ can reduce

- $\quad$ significantly the high cost of electricity by replacing current fossil fuel power plants with incineration that exhibit unit costs $(\$ / \mathrm{kWh})$ as low as wind energy [19], but has additional advantage of not being dependent on uncontrolled variables (e.g., natural synoptic conditions that determine wind occurrence, direction, and speed);

- the dependence of electricity supply on international trade (oil market and transportation in large vessels) due to insularity (Table 1);

- $\quad$ environmental impacts regarding global warming and terrestrial and aquatic ecosystem deterioration, respectively, due to GHG emissions and discharge of pollutants to soil and water bodies (Table 6).

Other recommendations for SIDSs and elsewhere include the following: (i) prioritize prevention/reduction of waste production, reuse for the same or another purpose, recycling, energy recovery, and disposal (landfilling); (ii) prioritize WtE with energy recovery at the expense of landfilling and make efforts to progressively apply thermal processing of mainly the non-biodegradable fraction of MSW, while composting and anaerobic digestion can be applied to manage the organics; (iii) strategic environmental assessment should be considered an unreplaceable tool to assess the feasibility and reliability of WtE projects; (iv) tourism utilities should be encourage to implement environmental management system to enforce waste prevention, reuse, and recycling.

It is worth mentioning that $80 \%$ of the combustible biomass present in MSW is considered renewable fuel, and because the US Department of Energy categorized MSW as biomass [9].

Thermochemical processes imply less use of land resources (reduce waste disposal and ecological footprint) and is aligned with the concept of the circular economy because it also entails energy recovery. Therefore, extensive implementation of WtE technologies in SIDSs is aligned with sustainable development goals and contributes to substitution of fossil fuel power plants, diversification of sources of energy, and security of supply.

According to the analysis performed, small municipalities in any country, either island or inland, might also promote public awareness concerning recycling as well as assess the feasibility (payback period of investments) of WtE plants instead of transporting MSW to distant landfills in other regions.

This work aims to provide politicians, managers, and practitioners with useful information and indicators (Table 2, Figures 3-5) to guide decision-making regarding MSW management, and renewable energy provision. The contribution of this work is relevant to define a roadmap for meeting the energy requirements, which is accomplished by considering multiple dimensions of sustainability (economy-including technology, environment, and society), diversification of natural energy sources to minimize importation, and rational use (energy conservation and efficiency) that impact long-term energy planning.

Author Contributions: Conceptualization, H.M.-L.; methodology, H.M.-L. and F.M.-D., bibliographical review, all authors; data collection, H.M.-L., D.W.S., D.C.N., S.A.K. and T.C.F.d.O.; writingoriginal draft preparation, H.M.-L.; writing—review and editing, H.M.-L., D.W.S., D.C.N., S.A.K., T.C.F.d.O. and F.M.-D.; visualization, H.M.-L.; supervision, H.M.-L.; project administration, H.M.-L. All authors have read and agreed to the published version of the manuscript. 
Funding: This research benefited from funding from PROEX-UNILA and LARSyS (Projeto-UIDB/ 50009/2020).

Institutional Review Board Statement: Not applicable.

Informed Consent Statement: Not applicable.

Data Availability Statement: Not applicable.

Conflicts of Interest: The authors declare no conflict of interest.

\section{References}

1. Song, J.; Yang, W.; Li, Z.; Higano, Y.; Wang, X. Discovering the energy, economic and environmental potentials of urban wastes: An input-output model for a metropolis case. Energy Convers. Manag. 2016, 114, 168-179. [CrossRef]

2. Rugani, B.; Roviani, D.; Hild, P.; Schmitt, B.; Benetto, E. Ecological deficit and use of natural capital in Luxembourg from 1995 to 2009. Sci. Total. Environ. 2013, 468-469, 292-301. [CrossRef] [PubMed]

3. International Energy Agency, IEA. Word Energy Outlook; International Energy Agency: Paris, France, 2008.

4. Xie, H. Legal Regulation of Low-Carbon Economy. IERI Procedia 2014, 8, 170-175. [CrossRef]

5. United Nations Department of Economic and Social Affairs Population Dynamics. The 2019 Revision of World Population Prospects. Available online: https:/ / population.un.org/wpp/ (accessed on 28 January 2019).

6. Mata-Lima, H.; Silva, F.; Alvino-Borba, A.; Almeida, J.A. Environmental Management in Organizations: Is ISO 14001 Implementation Growing Fast Enough to Improve Environmental Conditions in the Metropolitan Areas of Developing Countries? Environ. Qual. Manag. 2014, 24, 61-77. [CrossRef]

7. United Nations. Small Island Developing States and the UN-Timeline. Available online: https://www.un.org/en/events/ islands2014/smallislands.shtml (accessed on 18 September 2021).

8. United Nations. Percentage of Population in Urban and Rural Areas. Available online: https:/ / population.un.org/wup/CountryProfiles / (accessed on 18 September 2021).

9. Psomopoulos, C.; Bourka, A.; Themelis, N. Waste-to-energy: A review of the status and benefits in USA. Waste Manag. 2009, 29, 1718-1724. [CrossRef]

10. Pearce, D. Valuing natural resources and the implications for land and water management. Resour. Policy 1987, 13, 255-264. [CrossRef]

11. Sun, M.; Wang, J.; He, K. Analysis on the urban land resources carrying capacity during urbanization. A case study of Chinese YRD. Appl. Geogr. 2020, 116, 102170. [CrossRef]

12. Gao, Q.; Fang, C.; Cui, X. Carrying capacity for SDGs: A review of connotation evolution and practice. Environ. Impact Assess. Rev. 2021, 91, 106676. [CrossRef]

13. United Nations. The Millennium Development Goals Report 2010; United Nations: New York, NY, USA, 2010.

14. United Nations. Report of the United Nations Conference on Sustainable Development. Rio de Janeiro, 20-22 June 2012. A/CONF.216/16. United Nations, New York. Available online: http://www.uncsd2012.org/content/documents/814UNCSD\% 20REPORT\%20final\%20revs.pdf (accessed on 16 November 2015).

15. United Nations. Transforming our World: The 2030 Agenda for Sustainable Development. A/RES/70/1; United Nations: New York, NY, USA, 2015.

16. Wolf, F.; Surroop, D.; Singh, A.; Leal, W. Energy access and security strategies in Small Island Developing States. Energy Policy 2016, 98, 663-673. [CrossRef]

17. Mohee, R.; Mauthoor, S.; Bundhoo, M.A.Z.; Somaroo, G.; Soobhany, N.; Gunasee, S. Current status of solid waste management in small island developing states: A review. Waste Manag. 2015, 43, 539-549. [CrossRef] [PubMed]

18. UNDESA. SIDS Members States. Available online: https://sustainabledevelopment.un.org/index.php? menu=1520 (accessed on 20 February 2016).

19. Cucchiella, F.; D'Adamo, I.; Gastaldi, M. Sustainable management of waste-to-energy facilities. Renew. Sustain. Energy Rev. 2014, 33, 719-728. [CrossRef]

20. European Parliament. Directive 2012/27/EU of the European Parliament and of the Council of on Energy Efficiency, Amending Directives 2009/125/EC and 2010/30/EU and Repealing Directives 2004/8/EC and 2006/32/EC. Available online: https: / / eur-lex.europa.eu/legal-content/EN/TXT/PDF/?uri=CELEX:32012L0027\&from=EN (accessed on 20 September 2021).

21. European Parliament. Directive 2018/850 of the European Parliament and of the Council of Amending Directive 1999/31/EC on the Landfill of Waste. Available online: https://eur-lex.europa.eu/legal-content/EN/TXT/PDF/?uri=CELEX:32018L0850\& from $=$ EN (accessed on 20 September 2021).

22. Pressley, P.N.; Aziz, T.; DeCarolis, J.; Barlaz, M.A.; He, F.; Li, F.; Damgaard, A. Municipal solid waste conversion to transportation fuels: A life-cycle estimation of global warming potential and energy consumption. J. Clean. Prod. 2014, 70, 145-153. [CrossRef]

23. Torraco, R.J. Writing Integrative Literature Reviews: Guidelines and Examples. Hum. Resour. Dev. Rev. 2005, 4, 356-367. [CrossRef]

24. Seuring, S.; Müller, M. From a literature review to a conceptual framework for sustainable supply chain management. J. Clean. Prod. 2008, 16, 1699-1710. [CrossRef] 
25. Snyder, H. Literature review as a research methodology: An overview and guidelines. J. Bus. Res. 2019, 104, 333-339. [CrossRef]

26. Hampton, M.; Christensen, J. Competing industries in islands a new tourism approach. Ann. Tour. Res. 2007, 34, 998-1020. [CrossRef]

27. Scheyvens, R.; Momsen, J.H. Tourism and Poverty Reduction: Issues for Small Island States. Tour. Geogr. 2008, 10, 22-41. [CrossRef]

28. Noy, I. The macroeconomic consequences of disasters. J. Dev. Econ. 2009, 88, 221-231. [CrossRef]

29. Pratt, S. The economic impact of tourism in SIDS. Ann. Tour. Res. 2015, 52, 148-160. [CrossRef]

30. Grilli, G.; Tyllianakis, E.; Luisetti, T.; Ferrini, S.; Turner, R.K. Prospective tourist preferences for sustainable tourism development in Small Island Developing States. Tour Manag. 2021, 82, 104178. [CrossRef]

31. United Nations. World Population Prospects 2019. Data Booklet. Department of Economic and Social Affairs. Available online: https:/ / population.un.org/wpp/Publications/Files/WPP2019_DataBooklet.pdf (accessed on 20 September 2021).

32. Worlddata. Geograpgy. Available online: https://www.worlddata.info/ (accessed on 20 September 2021).

33. United Nations. World Population Prospects 2019. Available online: https://population.un.org/wup/Country-Profiles/ (accessed on 20 September 2021).

34. United Nations. UN Data-A World Information. World Development Indicators: GDP per Capita. Available online: http: / / data.un.org/Explorer.aspx (accessed on 20 September 2021).

35. World Bank. GDP per Capita. Available online: https://data.worldbank.org/indicator/NY.GDP.PCAP.CD?locations=BS (accessed on 20 September 2021).

36. United Nations. UN Data-A World Information. Available online: http:// data.un.org/Data.aspx?d=ENV\&f=variableID\%3a1814 (accessed on 20 September 2021).

37. European Parliament. Directive 2008/98/EC of the European parliament and of the Council of 19 November 2008 on waste and repealing certain directives. Off. J. Eur. Communities 2008, L312, 3-30.

38. Zhang, C.; Hu, M.; Di Maio, F.; Sprecher, B.; Yang, X.; Tukker, A. An overview of the waste hierarchy framework for analyzing the circularity in construction and demolition waste management in Europe. Sci. Total. Environ. 2021, 803, 149892. [CrossRef] [PubMed]

39. European Parliament. Directive 2008/1/EC of the European parliament and of the Council of 15 January 2008 concerning integrated pollution prevention and control. Off. J. Eur. Communities 2008, L24, 8-29.

40. Surroop, D.; Raghoo, P. Energy landscape in Mauritius. Renew. Sustain. Energy Rev. 2017, 73, 688-694. [CrossRef]

41. Themelis, N. The Role of Waste-to-Energy in Urban Infrastructure. In Metropolitan Sustainability; Understanding and Improving the Urban Environment; Woodhead Publishing Series in Energy: Sawston, UK, 2012; pp. 500-519. [CrossRef]

42. Clausen, A.; Pretz, T. The Relevance of Framework Conditions for Modelling GHG Emissions from rMSW Treatment Systems in EU. Waste Biomass Valorization 2015, 7, 175-191. [CrossRef]

43. Pavlas, M.; Touš, M.; Bébar, L.; Stehlík, P. Waste to energy-An evaluation of the environmental impact. Appl. Therm. Eng. 2010, 30, 2326-2332. [CrossRef]

44. Anshassi, M.; Sackles, H.; Townsend, T.G. A review of LCA assumptions impacting whether landfilling or incineration results in less greenhouse gas emissions. Resour. Conserv. Recycl. 2021, 174, 105810. [CrossRef]

45. Fazeli, A.; Bakhtvar, F.; Jahanshaloo, L.; Sidik, N.A.C.; Bayat, A.E. Malaysia's stand on municipal solid waste conversion to energy: A review. Renew. Sustain. Energy Rev. 2016, 58, 1007-1016. [CrossRef]

46. AlQattan, N.; Acheampong, M.; Jaward, F.M.; Ertem, F.C.; Vijayakumar, N.; Bello, T. Reviewing the potential of Waste-to-Energy (WTE) technologies for Sustainable Development Goal (SDG) numbers seven and eleven. Renew. Energy Focus 2018, 27, 97-110. [CrossRef]

47. Xin-Gang, Z.; Gui-Wu, J.; Ang, L.; Yun, L. Technology, cost, a performance of waste-to-energy incineration industry in China. Renew. Sustain. Energy Rev. 2016, 55, 115-130. [CrossRef]

48. Tabasová, A.; Kropáč, J.; Kermes, V.; Nemet, A.; Stehlík, P. Waste-to-energy technologies: Impact on environment. Energy 2012, 44, 146-155. [CrossRef]

49. Valerio, F. Environmental impacts of post-consumer material managements: Recycling, biological treatments, incineration. Waste Manag. 2010, 30, 2354-2361. [CrossRef] [PubMed]

50. Eurostat Municipal Waste Statistics-Statistics Explained. Available online: https://ec.europa.eu/eurostat/statistics-explained/ index.php?title=Municipal_waste_statistics (accessed on 10 October 2019).

51. Bruno, M.; Abis, M.; Kuchta, K.; Simon, F.-G.; Grönholm, R.; Hoppe, M.; Fiore, S. Material flow, economic and environmental assessment of municipal solid waste incineration bottom ash recycling potential in Europe. J. Clean. Prod. 2021, $317,128511$. [CrossRef]

52. Kalbe, U.; Simon, F.-G. Potential Use of Incineration Bottom Ash in Construction: Evaluation of the Environmental Impact. Waste Biomass Valorization 2020, 11, 7055-7065. [CrossRef]

53. Aracil, C.; Haro, P.; Fuentes-Cano, D.; Gómez-Barea, A. Implementation of waste-to-energy options in landfill-dominated countries: Economic evaluation and GHG impact. Waste Manag. 2018, 76, 443-456. [CrossRef] [PubMed]

54. Silva, R.; de Brito, J.; Lynn, C.; Dhir, R. Environmental impacts of the use of bottom ashes from municipal solid waste incineration: A review. Resour. Conserv. Recycl. 2018, 140, 23-35. [CrossRef] 
55. Di Maria, F.; Sisani, F.; Lasagni, M.; El-Hoz, M. An hybrid approach for primary energy balance of an existing waste-to-energy plant. Energy Procedia 2018, 148, 297-303. [CrossRef]

56. CEWEP. Cewep Energy Report III (Status 2007-2010). Available online: https://www.cewep.eu/cewep-energy-efficiencyreports/ (accessed on 20 September 2021).

57. Murer, M.J.; Spliethoff, H.; de Waal, C.M.W.; Wilpshaar, S.; Berkhout, B.; van Berlo, M.A.J.; Gohlke, O.; Martin, J.J.E. High efficient waste-to-energy in Amsterdam: Getting ready for the next steps. Waste Manag. Res. 2011, 29, S20-S29. [CrossRef]

58. CEWEP. Country Reports 2018. Confederation of European Waste-to-Energy Plants. Available online: https://www.cewep.eu/ country-reports-2018/ (accessed on 20 September 2021).

59. Khoodaruth, A.; Oree, V.; Elahee, M.; Clark, W.W. Exploring options for a $100 \%$ renewable energy system in Mauritius by 2050. Util. Policy 2017, 44, 38-49. [CrossRef]

60. Shah, K.U.; Niles, K. Energy policy in the Caribbean green economy context and the Institutional Analysis and Design (IAD) framework as a proposed tool for its development. Energy Policy 2016, 98, 768-777. [CrossRef]

61. Sewak, A.; Deshpande, S.; Rundle-Thiele, S.; Zhao, F.; Anibaldi, R. Community perspectives and engagement in sustainable solid waste management (SWM) in Fiji: A socioecological thematic analysis. J. Environ. Manag. 2021, 298, 113455. [CrossRef]

62. Aryampa, S.; Maheshwari, B.; Zamorano, M.; Sabiiti, E.N.; Olobo, C.; Bateganya, N.L. Adaptation of EVIAVE Methodology to Landfill Environmental Impact Assessment in Uganda-A case study of Kiteezi Landfill. J. Afr. Earth Sci. 2021, $183,104310$. [CrossRef]

63. Münster, M.; Meibom, P. Optimization of use of waste in the future energy system. Energy 2011, 36, 1612-1622. [CrossRef]

64. Tan, S.T.; Hashim, H.; Lim, J.S.; Ho, W.S.; Lee, C.T.; Yan, J. Energy and emissions benefits of renewable energy derived from municipal solid waste: Analysis of a low carbon scenario in Malaysia. Appl. Energy 2014, 136, 797-804. [CrossRef]

65. Curry, N.; Pillay, P. Biogas prediction and design of a food waste to energy system for the urban environment. Renew. Energy 2012, 41, 200-209. [CrossRef]

66. Siddiqi, A.; Haraguchi, M.; Narayanamurti, V. Urban waste to energy recovery assessment simulations for developing countries. World Dev. 2020, 131, 104949. [CrossRef]

67. Tozlu, A.; Ozahi, E.; Abuşoğlu, A. Waste to energy technologies for municipal solid waste management in Gaziantep. Renew. Sustain. Energy Rev. 2016, 54, 809-815. [CrossRef]

68. Cheng, H.; Hu, Y. Municipal solid waste (MSW) as a renewable source of energy: Current and future practices in China. Bioresour. Technol. 2010, 101, 3816-3824. [CrossRef]

69. Dvořák, R.; Pařízek, T.; Bébar, L.; Stehlík, P. Incineration and gasification technologies completed with up-to-date off-gas cleaning system for meeting environmental limits. Clean Technol. Environ. Policy 2008, 11, 95-105. [CrossRef]

70. Gohlke, O.; Weber, T.; Seguin, P.; Laborel, Y. A new process for NOx reduction in combustion systems for the generation of energy from waste. Waste Manag. 2010, 30, 1348-1354. [CrossRef] [PubMed]

71. Neehaul, N.; Jeetah, P.; Deenapanray, P. Energy recovery from municipal solid waste in Mauritius: Opportunities and challenges. Environ. Dev. 2019, 33, 100489. [CrossRef] 